\title{
The semiotics of verse rhythm and comparative rhythmics: Vladimir Nabokov's and Jurgis Baltrušaitis's binary tetrameters from a typological perspective
}

Mihhail Lotman*

\begin{abstract}
The article discusses the problems of poetic rhythm in two aspects. The first concerns the possibility of awareness and conscious modelling of various aspects of poetic rhythm; the second is related to the manifestation of similar or even identical tendencies in the rhythmic structures of various authors who belong to different eras and literary trends and even writing in different languages. Works from bilingual authors such as Vladimir Nabokov and Jurgis Baltrušaitis are of the particular interest.

The first half of the article focuses on how the concept of rhythm proposed in the book by Andrei Bely (1910) influenced the poetic practice. Before Bely, it had been implicit that the choice of stanzaic and metric forms was usually conscious for authors, while Bely demonstrated that poets and their audience can be aware of verse rhythm as well. After the publication of his results, Bely and other poets of a predominantly Symbolist approach began to pay attention to the rhythmic structure of the verse and made attempts to model it. Considered are the following problems: a) how do poetic meters relate to rhythmic forms; b) to what extent can the rhythmic momentum be recognized by the author, and to what extent can the author influence it; and c) how can the author compose verses in accordance with a pre-selected rhythmic model.

In the second half of the article, the rhythm of iambic and trochaic tetrameters in Russian poetic heritage of Jurgis Baltrušaitis is analysed in comparison with the rhythm of his Lithuanian verses. As it turns out, despite the obvious differences in the prosody of the Lithuanian and Russian languages, the rhythmic structure of his poems obeys the same regularities.

In the final part of the article, possible explanations of rhythmic patterns are proposed and an outline of the typology of the rhythm of the binary tetrameters is given.
\end{abstract}

Keywords: rhythmics; binary tetrameters; semiotics of verse; Andrei Bely; Nabokov; Baltrušaitis

* Author's address: Mihhail Lotman, Department of Semiotics, University of Tartu, Jakobi 2, 51014 Tartu, Estonia, e-mail: mihhail.lotman@gmail.com. 


\section{Introduction. Verse rhythm: the problems of its nature and its meaning}

Ever since the Russian Formalists, there has been a distinction between meter and rhythm in versification: meter is an ideal structure, while rhythm is its concrete realization; a different set of rhythmic forms corresponds to each meter (compare Pilshchikov 2017). In most cases, the choice of meter is conscious, and the choice of rhythm is not.

Nevertheless, rhythm - as all the other elements of aesthetic structure can be conscious and not only studied and described, but also intentionally modelled. Modernist poetry experiments with both meter and rhythm. In the beginning of the 20th century Andrei Bely, Valery Bryusov and several lesser known Symbolists actively experimented with rhythm.

This experimentation raises two questions. The first is connected to the problem of autonomy of verse rhythm: does it automatically stem from the qualities of verse meter and language (for example, syntax), or does it have its own regularities? When Mikhail Lomonosov founded the tradition of the Russian iambic tetrameter, he followed Martin Opitz's instructions. On the one hand, his iambic tetrameter has four iambic feet, that is, four stresses; at the same time, however, he followed the rhythmics of German iamb, and here he used Johann Christian Günther's oeuvre as a prototype, first of all, his ode written in 1718 . The prosody of the German language is considerably different from that of the Russian language, and it took some time before the influence of Russian prosody reached Lomonosov's poetry. There are other examples as well where verse rhythm is influenced by a particular foreign verse tradition. Jaak Põldmäe demonstrated how translating "Eugene Onegin" has influenced Betti Alver's rhythm in her original Estonian poetry (Põldmäe 1975). In a similar way, Vikram Seth uses, in his verse novel "The Golden Gate" which is written in Onegin stanzas, the rhythm forms which are very rare in English iambs, but regular in Pushkin's iamb and are, in a way, his impresa (the fourth paeon). Similar rhythm forms can be found in Onegin stanzas by Diana Burgin. In Seth's case it is especially remarkable that he did not know Russian and studied Pushkin's 'novel in verse' from secondary sources. Diana Burgin, on the other hand, is a Slavist, and knows Pushkin's works comprehensively.

The second question of experimentation is, how free the poets are in a conscious modelling of verse rhythm, and how far they can move from meter as its prototype so that it could be still perceived as a rhythm of this meter. Innokenty Annensky asked if the second and the fourth paeon are the same meter or two different ones and Andrei Bely's analysis showed that they are the same meter: iambic tetrameter. These are two different rhythm types of the 
same verse meter. But what about Tyutchev's "Last Love"? Is it still an iambic tetrameter, or is it some other verse form ${ }^{1}$ ?

If a certain rhythmic regularity arises in the works of an author, group of authors or literary period, it forms a rhythm type: for example, there is a rhythmic type which is characteristic to the 18th century Russian iambic tetrameter, and another to that of the 19th century; Kiril Taranovsky described three different rhythmic types in Andrei Bely's iambic tetrameter. Thus, different rhythm types can coexist in the same meter. But, can the same rhythmic regularities occur in different meters? Or even more importantly, can the same rhythmic types occur in verses in different languages?

\section{2. lamb and paeon: two different meters or different rhythm forms of the same meter?}

In 1910, Innokenty Annensky published the collection Cypress Box (Kiparisovyj larets); one of the sonnets included in the collection begins with the quatrain:

На службу Лести иль Мечты

Равно готовые консорты,

Назвать вас вы, назвать вас ты,

Пэон второй - пэон четвертый?

(Annensky 1990: 133)

At the service of Flattery or Dream,

[You are] equally ready consorts,

[Shall I] call you 'you' [plural], [or shall I] call you 'thou' [singular],

Paeon the second - paeon the fourth?

The title of the poem is "Paeon the second - paeon the fourth" ("Peon vtoroj peon chetvertyj"). To understand this fragment, one must know both the historical and poetological background. At the beginning of the 20th century various Russian poets - all of them representatives of Symbolism - began to study versification. The most successful was Andrei Bely (real name: Boris Bugaev), whose book Symbolism published in 1910 marks the birth of modern

\footnotetext{
1 Fedor Tyutchev's famous poem "Last Love" ("Poslednjaja ljubov") which is written on the basis of the iambic tetrameter. However, in five lines of twelve, there are violations that are not permissible in iamb.
} 
statistical analysis of verse. It is tempting to associate Annensky's poem with Bely's results, yet this may not be chronologically correct, since Annensky presumably created his poem before the publication of Bely's work. The work by Bely and by the rhythmic studies group that he led was preceded by studies conducted by other remarkable Symbolists - Valery Bryusov and Vyacheslav Ivanov. In any case, the questions regarding versification formed a central focus for the Symbolists.

In 1934, Vladislav Khodasevich recalled:

"We [i.e. the poets and foremost the Symbolists - ML] were tormented by the question: what, besides phonics, ensures the difference in sound in the same verse meter? In the summer of 1908, [Bely] called me and laughingly yelled: “[...] I have made a discovery! A true discovery, like Archimedes!" I of course came over [...]. On the table was a gigantic pile of papers with vertical columns drawn on them. The columns contained spots which were connected to each other with straight lines in a complex fashion. Bely patted the pile with his palm: "Here is the entirety of iambic tetrameter. Just in the palm of your hand. The verses of the same meter are differentiated by rhythm. The rhythm does not coincide with meter and is defined by the omission of metrical stress. "Moi djadja samykh chestnykh pravil" has four stresses, but "I klanjalsja neprinuzhdenno" has two: the rhythm is different, but the verse meter is the same - iambic tetrameter. These have become by now common knowledge. On that day, however, it was a discovery, indeed simple and surprising, just like in the case of Archimedes." (Khodasevich 2012: 41-63).

According to Andrei Bely, meter is the central point (at present we would call it the prototype), from which rhythm diverges towards different directions: in one are the patterns that lack metrical stress in the first foot, in another the patterns have the second foot with no stress, and in the third direction the patterns are without stress on the third foot; the stress may be simultaneously absent from the first and the second, the first and the third, and the second and the third verse foot. Altogether, Bely distinguishes between seven different rhythmic forms. Bely devised a method of statistical analysis of rhythm which is used with certain corrections to this day. The results of the analysis are no less important. As it turns out, the rhythm of iambic tetrameter was different in the 18th and 19th centuries: the index of stressedness of the first foot is higher in the 18th century than that of the second foot, while the opposite holds for the 19th century, when the first verse foot was weaker than the second (Bely 1910: 262-264). One could say, using the terminology of that era, that in the 18th century the rhythmical momentum of I4 was formed with the second paeon $(\cup \smile \cup \cup)$, while in the 19th century it was with the fourth paeon ( $\cup \cup-)$. 
This is exactly what Annensky had in mind in his sonnet: in 18th-century Russian neoclassicist poetry I4 appears, first of all, in odes ("flattery"), during the 19th century - in elegies and romantic poems ("dreams"). Here he asks the question: do the differences in the rhythmics of the 18th and 19th century call for the necessity to treat these as different verse meters or the same meter: "Shall I call you 'you' or 'thou"'? For Annensky, the rhythmic form is an indexical sign, which points to a certain tradition and probably even a genre.

The question of the paeon arose later in a fairly curious context. On September 13, 1942, Vladimir Nabokov writes to Edmund Wilson:

Dear Bunny,

It took me exactly ten minutes to compose the following little masterpiece consisting exclusively of 4th paeons, a sequence that is seldom found even in Russian prosody.

The complicated variation of Lepidoptera affords a fascinating occupation for proletarians and lords.

And here is the same thing in Russian:

\author{
Разнообразное сложенье \\ чешуекрылыхъ мотыльковъ \\ уготовляетъ услажденье \\ для королей и бъдняковъ. \\ (Karlinsky 2001: 92)
}

There is no explanation in the letter as to what drove him to create this "little masterpiece". "The same thing in Russian" is not the exact translation of the English quatrain: the 'proletarians and lords' are replaced with 'kings and paupers' etc., but it is not Nabokov's goal here to attain the exact correspondence of content, but rather that of the rhythm: both quatrains have the 4th paeon for this, that is, the rhythm form VI of I4, according to the Bely-Kolmogorov numeration ${ }^{2}$. Nabokov is right here: the sequences of this rhythmic pattern

2 Compare the list of the rhythm forms of Russian iambic tetrameter in Igor Pilshchikov's paper (2019: 54). Andrei Bely's list was not originally numerated, it was numbered by Kiril Taranovsky (1953), Bely's numeration was later adjusted by Georgy Shengeli (Shengeli 1923: 
are very rare in Russian iamb and appear mostly in experimental poetry; in English iamb, even solitary 'paeonic' verses do not occur. ${ }^{3}$

Nabokov's miniature is not merely a tour de force, this joke has a touch of bitterness. In the previous correspondence, Wilson and Nabokov attempt to teach the rules of prosody to each other and often do it in a condescending tone. Wilson is more modest, he tries to prove that Nabokov misunderstood English prosody while making disparaging comments in passing about Russian verse theory, while Nabokov makes his way into the field of English prosody. Quoted is Nabokov's attempt to counter Wilson's complaints in a letter sent on September 1. Wilson:

"Now about the metrics: the terminology you use - of amphibrachs, pyrrhics, etc. - is obsolete in English. We now speak of these feet only in analyzing choruses from Greek plays - because Greek verse is quantitative and you have feet made up of combinations of long and short syllables and require special names to designate them. Thus, in this line from the Agamemnon-

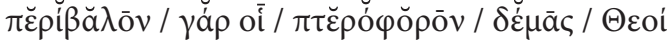

$\pi \varepsilon \rho i \beta a \lambda$ ov and $\pi \tau \varepsilon \rho o ́ \varphi o \rho o v$ are paeons; but when an English-speaking reader reads them, he accents the first syllable of each word, imposing on the line his own metrical system (nobody seems to know what the Greeks did, because nobody seems to know precisely what the written Greek accent indicated); and since we have got away in English in prosody as well as in grammar from trying to fit English into the molds of the Classical languages, we have simplified our

139-141), who changed the places of forms V and VII. Shengeli's version became popular thanks to Andrei Kolmogorov, it was also used by Mikhail Gasparov.

3 Years ago I studied more than 200,000 verses of English iambic tetrameter from the 18th until the first half of the 20th century and I did not find a single line that could have been interpreted as the V, VI or VII rhythm form; however, Nabokov (1964: 458-461) brings some examples of English I4 with two stresses. Overall, lines with two stresses are extremely rare in English I4, like, for instance, Byron's And Cupola and minaret ("Venice. A fragment"), where the stress falls on the second and the sixth syllable (Russian iamb does not contain such lines and they do not fit inside the Bely-Kolmogorov classification, since the 8th syllable - the socalled stress constant - has remained unstressed). Yet I did find both the VI and VII rhythm forms in two works created during the second half of the 1980s: Vikram Seth's The Golden Gate (1986) and Diana Lewis Burgin's Richard Burgin: A Life in Verse (1988). Both are written in Onegin stanzas and influenced by Russian prosody. Compare the VI rhythm form: Sentimentality behind, Irritability and charm (Seth), Half-anecdotal, half-scholastic, What unbelievable frustration (Burgin); the VII rhythm form: No herb of reconciliation, Of hatred, the intoxication (Seth), The concerts of the Philharmonic, An urgency apocalyptic (Burgin). 
metrics to five kinds of feet. We couldn't have any such thing as a line beginning $\cup \cup \cup$ - in English, so we don't need to talk about fourth paeons (If they taught you those other feet in school, the analysis of Russian verse - which seems to me basically, from the point of view of metrics, just like English verse, as you say then the Russian discussion of prosody was still in a backward state).

Our five English feet are these: trochee, iambus, anapest, dactyl, spondee. We do not need any more. The notation is the same we use for Greek and Latin, but here the little curves mean unaccented syllables instead of short syllables, and the dashes mean accented syllables instead of long syllables. (Sometimes they write a / instead of a dash; but I have got into the habit of writing in the other way.) These five feet suffice for analyzing any English verse. In our metrics,

or U

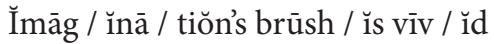

is scanned like this."

(Karlinsky 2001: 89)

The latter example should mean that the beginning of the verse, where Nabokov mistakenly sees a paeon (imagina... $\cup \cup \cup$-), has two iambs according to Wilson (imag/ina... $\cup-/ \cup$-). Paeons, and so on, according to Wilson should remain for the analysis of ancient Greek choruses.

In this case, Nabokov did not delve into theoretical discussion, but responded with two poems: with a paeonic piece inserted in a letter and later with a longer amphibrachic poem, "Exile", which Wilson held in high regard. Wilson's letter was in turn an answer to Nabokov's voluminous letter from August 24, in which he thoroughly explains the foundations of Russian rhythmics by deriving first and foremost from Andrei Bely's treatment, developing it further in an original way and even attempting to demonstrate that the English iamb is founded on the same principles (Karlinsky 2001: 85). It is here that Nabokov introduced 'paeons' to describe the rhythm of I4. "[O]wing to the presence of some long adjective "неугомо́нная забота" or "таинственныя времена" the line may consist of two 'fourth' paeons $\cup \cup \cup$ ' $\cup U$ ' $U$ ' or a 'second' paeon plus a 'fourth' one $\cup-\cup \cup \cup \cup \cup$-'" (Karlinsky 2001: 81). However, Nabokov emphasises that this terminology and the corresponding transcription are purely conditional and the line "неугомонная забота" ("neugomónnaja zabóta”) can be designated either as $\cup \cup \cup^{\prime} \cup \cup \cup \cdot-[\cup]$ or $\cup-\cup^{\prime} \cup-\cup-[\cup]$, but the second designation is the clearer one as it shows the rhythmic relation of a concrete line to its abstract basic meter (Karlinsky 2001: 81).

This means that Nabokov is considerably sharper and more modern than Wilson, who stood confined to the so-called school metrics: To Nabokov, verse 
feet are conventional terms that represent an abstract system, but not the actual pronunciation: the differentiation between versification (stikhoslozhenie) and verse pronunciation (stikhoproiznesenie) was common in Russian verse theory. ${ }^{4}$

Andrei Bely created the foundations of Russian statistical verse doctine, but by the 1940s his views and methods of analysis were largely outdated due to the work of Boris Tomashevsky, Viktor Zhirmunsky and others. Nevertheless, Bely is the only author that Nabokov refers to with respect to rhythmic analysis, and whose ideas he uses and elaborates on. Most likely this was due to the fact that Nabokov deliberately ignored everything coming from the Soviet Union and the Formalists, who had by then fallen into disdain, were nevertheless associated with Bolshevism by him. ${ }^{5}$

The analysis of verse line in Bely's book turned out to be extremely productive, but the author's goals were much more ambitious: he devised a method which allowed for the visualisation of dynamic rhythm and considered this type of analysis to be particularly important. The complicated patterns formed by the spots connected with straight lines that Khodasevich saw on Bely's table were the results of such analysis. "A figure is the connection of two or more verses that deviate from the meter in a similar or different way; by connecting with straight lines the points of acceleration [uskorenie - another of Bely's failed terms denoting the absence of metrical stress $-\mathrm{ML}$ ] represented by dots we get the figure" (Bely 1910: 300-301).

It unfortunately turned out later that this part of Bely's tractate was not scientifically valid: despite numerous attempts, no correlation was found between rhythmical forms in adjacent lines (Tomashevsky 1929, Vasyutochkin 1968, Baevsky 2001). However, being insignificant from the viewpoint of verse theory, the 'graphic' considerably affected the consciousness of many poets. Nabokov was one of those poets. In the novel The Gift (1933-38) this method appears twice. Firstly, the talentless poet Yasha Chernyshevsky sketched these schemes in his notebooks. Secondly, the main character and another poet, Fyodor Godunov-Cherdyntsev, after studying 'Bely's monumental research' and estimating critically his own poetry, concluded that it was poor from

4 Compare Trubetzkoy 1987: 360. Unfortunately, Nabokov used the unsuccessful term 'halfaccent' (poluudarenie) which was inherited from Bely. He did not use it to mark the secondary stress, but the lack of stress in a metrically strong position; this probably confused Wilson.

5 However, Nabokov probably knew some things about the Formalists, in any case he makes two Freudian errors by wrongly naming Bely's book. Compare: "I shall have to suggest your perusing the treatise Poetica by Andrei Bely which is probably the greatest work on verse in any language" (Karlinsky 2001: 86). The matter at hand is that the name of Bely's tractate is Symbolism, while Poetica is the second title of Boris Tomashevsky's Theory of Literature (Poetica) (Tomashevsky 1925). 
the viewpoint of figures and decisively changed his style. We also know that Nabokov himself analysed the works of his and others in this manner.

We also encounter such treatments and schemes in his letters to Wilson. Let us give a simple example. Nabokov is analysing the following excerpt from Pushkin's “Count Nulin” (1825):

Она Тарквинию с размаха

Дает - пощечину, да, да,

Пощечину, да ведь какую!

Сгорел граф [in Nabokov's quotation: мой - ML] Нулин от стыда,

Обиду проглотив такую;

Не знаю, чем бы кончил он,

Досадой страшною пылая,

Но шпиц косматый, вдруг залая,

Прервал Параши крепкий сон.

Услышав граф ее походку

И проклиная свой ночлег

И своенравную красотку,

В постыдный обратился бег.

Как он, хозяйка и Параша

Проводят остальную ночь,

Воображайте, воля ваша!

Я не намерен вам помочь.

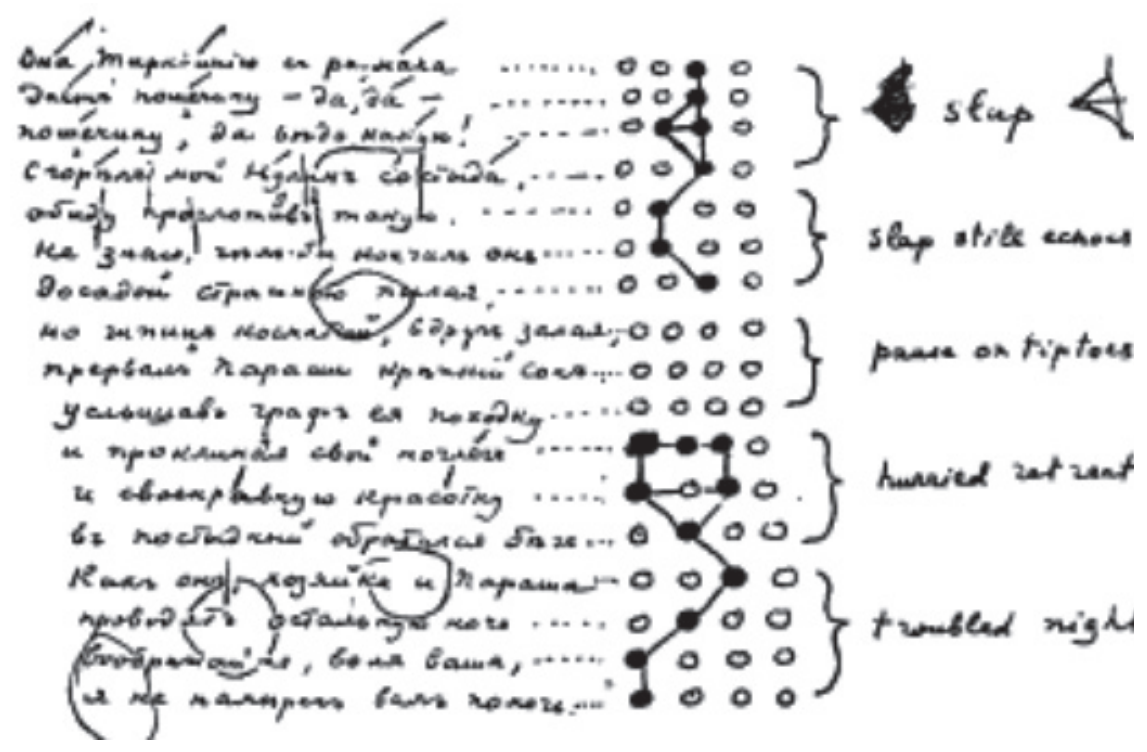


The first column has the text, then the scheme where the black dots mark the lacking metrical stresses, after that the summary of action (slap, ..., troubled night), then the figure itself.

As said previously, these graphics were not only a method of analysis for Nabokov, but also one of creation. In the novel The Gift, he describes the poetry of Godunov-Cherdyntsev's youth, which is poor in figures. Below is this quatrain as an example, to which we add our own scheme.

Mjàch zakatílsya mój pod njánin

komód, i na polú svechá

ten' za kontsý berjót i tjánet

tudá, sjudá, - no nét mjachá.

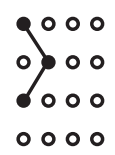

When the character reaches his bleak result, he begins to write completely differently so that there would be a lot of figures, and that they would be complex. In 1961, the novel was translated into English, with Nabokov himself translating its poems. Thus the 'elaborately' rhythmed quatrain looks like this in the original and the rhythmically identical translation, we also add a rhythmic scheme following the method of Bely-Nabokov.

Zadúmchivo i beznadézhno rasprostranjáet aromát i neosushchestvímo nézhno uzh poluuvjadáet sád.

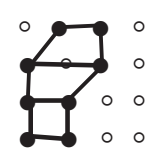

In miserable meditations, And aromatically dark, Full of interconverted patience, Sighs the semidenuted park.

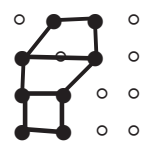

(Nabokov 1991: 151)

Both the Russian original and especially the English translation have a particularly refined rhythm. Andrei Bely was not able to find any rhythm form V (VII, according to other numeration) and brought an artificial example: I velosipedist letit $\left(\cup-\cup-\cup^{\prime} \cup^{\prime}\right)^{6}$. Yet here, both in the original and in the translation, two such lines occur in a sequence.

Yet that is not all. Nabokov, the master of hiding, secrets and mimicry (compare Hansen-Löve 2000) not only brings forth the rhythmic figures

6 Bely claimed, relying on his memory, that he saw one such line in the poem dedicated to Nikolai Yazykov by Karolina Pavlova (Bely 1910: 294-295), and the poem "N. M. Yazykovu. Otvet" ("To N. M. Yazykov, In Reply", 1840) contains indeed the following verse line: Dlia polugorodskíkh poléj (Для полугородских полей). Both according to Bely’s own and existing conventions, the rhythm forms are determined only by main stresses, hence, this line should be indeed approached as the form $\mathrm{V}$ (at the same time, in the word polugorodskikh the first syllable carries a secondary stress). 
but sometimes also skilfully hides them. Observe in the poem "Ursa Major" ("Bol'shaya medveditsa", September 23, 1918): Oleg Fedotov discovered that a scheme of the constellation is encoded into it, which is also alluded to in the seven verse lines and the images of 'seven maids' and 'seven stars' (Fedotov 2017; 2015: 282-308).
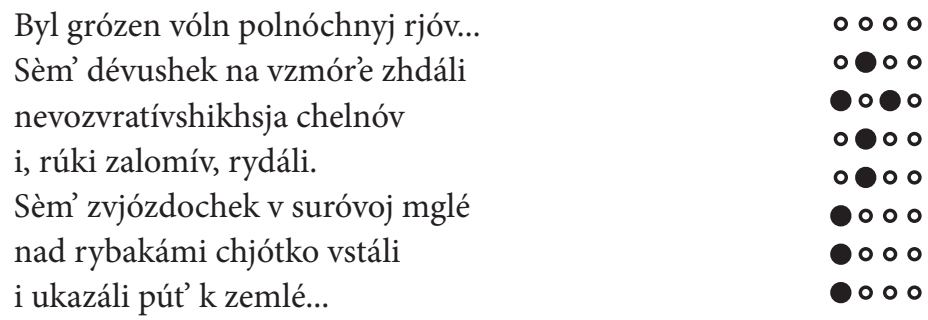

Let us summarise. When Andrei Bely started his studies of verse rhythm and opposed meter and rhythm he derived from the fact that if the choice of verse meter is deliberately chosen by the author and recognizable by the listener/ reader, then rhythm is not the result of conscious choices, but of subconscious processes. Meter is loaded with associations stemming from traditions, but rhythm expresses only the intratextual impulses and movements. In a similar vein, John Hollander distinguished between the semantics of meter and the semantics of rhythm: the former is like an emblem that connected the text and hand to another created in the same verse meter, the semantics of rhythm is related to various intratextual effects like contrast, entanglement, flow, and so on (Hollander 1959, 1975).

After the acknowledgment of rhythm and the description of some of its regularities it became possible to knowingly model it and use it as an emblem. Thus, different Russian modernists in the beginning of the 20th century deliberately used both the rhythm referring to the 18th century and the pronouncedly harmonious 19th century rhythm. Innokenty Annensky himself did not experiment with rhythm, but his sensitive instinct allowed to specify the emblematics of rhythm. Andrei Bely created an unprecedented asymmetric and stumbling rhythm of I4 to describe horrible things (Taranovsky 2000): new themes needed corresponding rhythms. And finally, Vladimir Nabokov semantisized meta-rhythm: not the rhythmic movement itself, but its description.

Let us finish this section, as we started, with the question of paeon. In 1916, Vladislav Khodasevich wrote a small poem "Paeon and caesura. Trefoil of meanings" ("Peon i tsezura. Trilistnik smyslov"): 
Pokórstvujushchij vsém zhelán’jam

Taínstvennoj vladéet siloj:

Tsezúra govorít molchán’em -

Peón ne prekoslóvit míloj.

No lásk neterpelívo prósit

Podrúga - i v soznán’e vlásti

On médlenno glavú voznósit,

Rastjágivaja zvén’ja strásti.

Every line starts with a paeon followed by two iambic feet. Accordingly, we are dealing with iambic tetrameter and its rhythm form III. However, since such monotonous rhythm embraces the whole text, Sergei Mazur in his detailed analysis interprets it as a logaoed (Mazur 1990: 89). Thus, the paeon is in the beginning of the line, but where are the caesurae? It appears that they form a certain pattern, which is in harmony with the content of the poem, having an erotic meaning: Caesura (feminine gender) impatiently asks Paeon (masculine gender) to "caress" her (line 5), but he is "prolonging the links of passion" (last line).

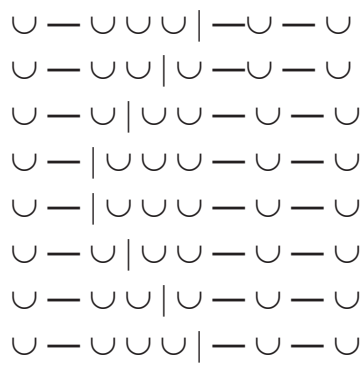

Here we can see a more refined play, even as compared with Bely's "figures" in Nabokov's poem: they varied different forms of the same meter, whereas Khodasevich takes one rhythmic form and creates a pattern from variations of its word-boundaries. Just like in Nabokov's "Ursa Major", this picture can be obtained only as a result of the analysis. 


\section{Comparative rhythmics}

Comparative versification study belongs among the more recent fields of verse studies, especially as concerns the research of comparative rhythmics. While in the fields of metrics and systems of versification numerous valuable results were achieved already in the 19th century, the comparative analysis of rhythm in different poetic systems has only become possible with the development of the statistical method. The studies by Kiril Taranovsky, Mikhail Gasparov, Marina Tarlinskaja and others are more widely known; of the most recent treatments, one can also refer to the works of Evgeny Kazartsev (compare especially $2017:$ : $134-150)^{7}$.

The legacy of bilingual poets is a gratifying material from the perspective of comparative verse study. Unfortunately, while there is a fair amount of bilingual poets, their literary heritage rarely contains enough material to allow for comparative statistical analysis of rhythm.

Kiril Taranovsky has described the rhythmics of Taras Shevchenko's iambic tetrameters (I4) by comparing his Ukrainian and Russian poems. The result is more than meaningful: in Shevchenko's Ukrainian I4 and his early Russian I4, there is an exact correspondence between the indices of average stressedness of the metrically strong positions $\left(\alpha_{1}, \alpha_{2}, \ldots, a_{n}\right)$; since the groundbreaking works by Andrei Bely, the stressedness of strong position has been considered the main parameter of rhythm.

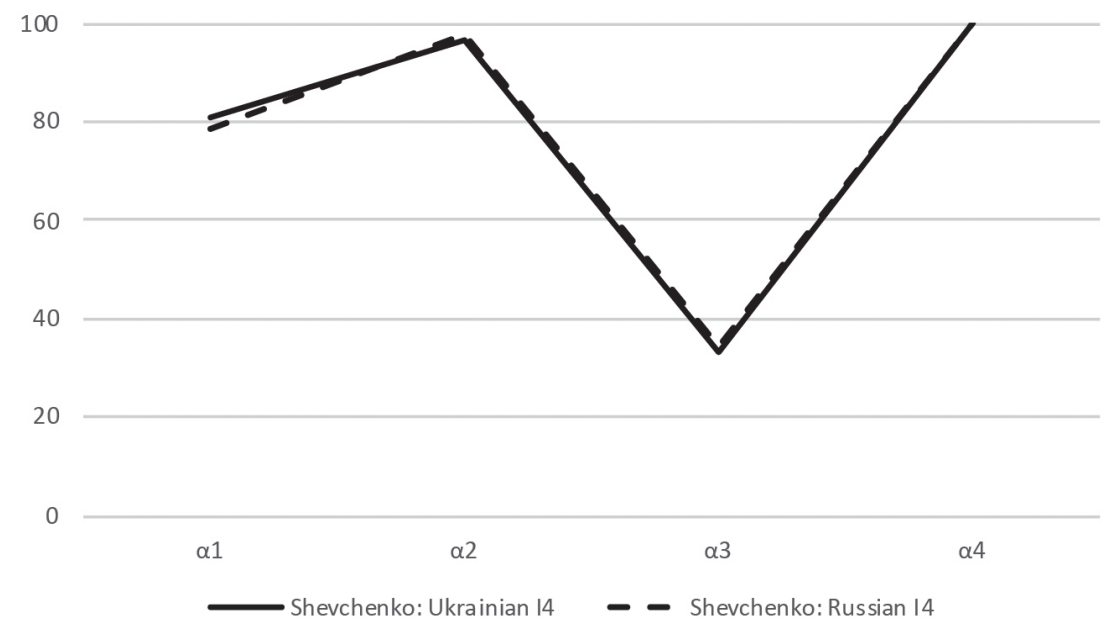

Chart 1. Ukrainian and Russian 14 in Taras Shevchenko's poem (Taranovsky 2010: 49)

7 The results of many studies have been presented in the monograph Lotman, Lotman 2018 (see especially 2018: 319-342). 
Furthermore, it can be confirmed that the rhythmic momentum of Taras Shevchenko's Ukrainian poetry is quite close to the rhythmic tendencies which characterized Russian poetry of the same period (for example, the works by Pushkin and especially his successors). Compare the stress profile in Sevchenko's Ukrainian I4 with the analogous data in Baratynsky's I4:

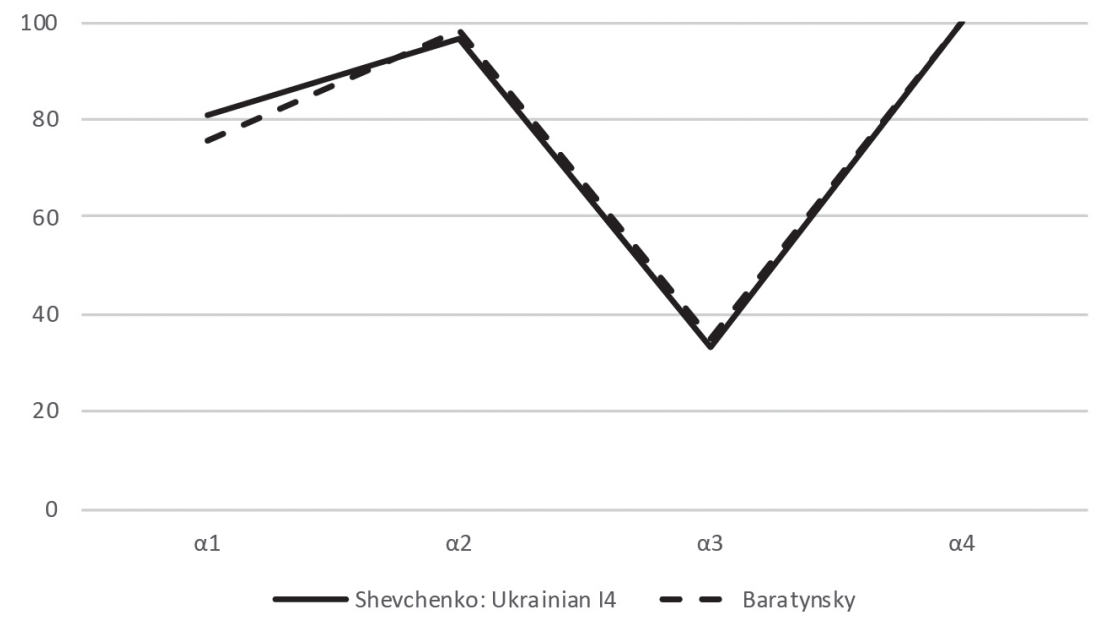

Chart 2. The rhythmics of Taras Shevchenko's Ukrainian 14 in comparison with the rhythmics of Yevgeny Baratynsky's 14 (Taranovsky 2010: 449-453)

Both cases demonstrate dissimilative rhythm: $\alpha_{4}>a_{2}>a_{1}>a_{3}$, which is characteristic to Russian I4 in the post-Pushkin era. However, the question inevitably arises, whether the aforementioned patterns are the result of the influence of cultural factors or is the rhythmics of Shevchenko's I4 determined solely by the prosodic parameters of the Ukrainian language, while the correspondence with the rhythmics of Russian I4 is merely a consequence resulting from the closeness of the languages or even random in the first place?

There were no bilingual Ukrainian-Russian poets before Shevchenko who could have left a significant iambic heritage. However, it is useful to compare Ivan Kotliarevsky's Ukrainian Eneida (1798) with Nikolai Osipov's Russian poem Virgilieva Eneida, vyvorochennaja naiznanku (Virgil's Aeneid Travestied, 1791-1796); as we know, Kotlyarevsky's work is a free translation of Osipov's poem. 


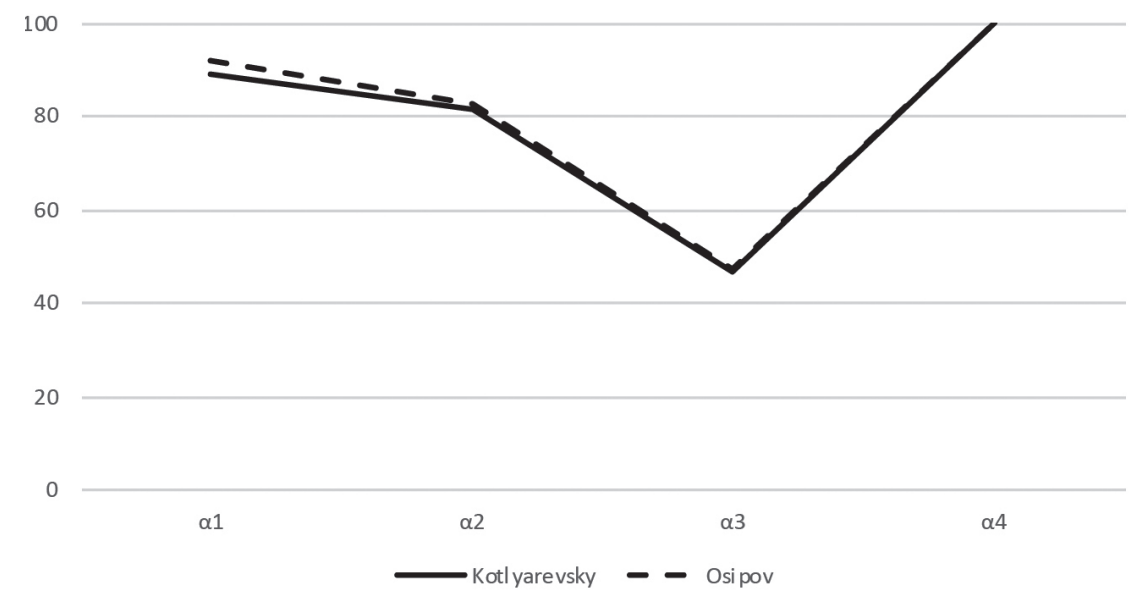

Chart 3. Ukrainian and Russian 14 in Kotlyarevsky's Eneida and Osipov's original (Taranovsky 2010: 446-447)

Here, too, the rhythmic contours essentially overlap, but they are fundamentally different in comparison with Shevchenko's verse. Here, the hierarchy of the stressedness of the strong positions is $\alpha_{4}>\alpha_{1}>\alpha_{2}>\alpha_{3}$, which is characteristic of 18th-century Russian I4.

\section{Regularities of rhythm}

By analysing a considerable bulk of 18th- and 19th-century verses in Russian binary meters, Kiril Taranovsky formulated two statistical laws of Russian rhythmics: the law of the stabilisation of the first strong position after the first weak position, and the law of regressive dissimilation (Taranovsky 1953). ${ }^{8}$ Both laws explain the hierarchy of the stressedness of the strong positions in a verse line. In accordance with the first law, the first strong position stands out with higher occurrence of stresses if it is preceded by a weak position, as it is in iamb. However if a verse line starts with a strong position, as it is in trochee, the higher stressedness characterizes not the first, but the second strong position. In other words, the second syllable is prominent in iamb, the third

8 In Kiril Taranovsky's formulation: "the law of the stabilization of the first ictus after the first weak position in the line" (Taranovsky 2010: 409) and "the law of regressive accentual dissimilation" (Taranovsky 2010: 325). 
syllable in trochee. ${ }^{9}$ According to the second law, the last position of the verse is the most stressed, which is in contrast with the penultimate position, being the weakest, the antepenultimate position has again higher stress while still being weaker than the last strong position etc. These laws show interaction in the following manner: they harmonize in trochees with even-numbered feet (dimetric, tetrametric, hexametric verse) and in iambs with odd-numbered feet (trimetric and pentametric verse), amplifying each other; they clash in trochees with odd-numbered feet and iambs with even-numbered feet, resulting in the law of stabilisation inhibiting the law of dissimilation in the first hemistich during the 18th century; in the 19th century the law of dissimilation becomes stronger than the law of stabilisation while nevertheless not completely oppressing it. In reference with the Russian I4, Mikhail Gasparov called the the 18th-century type of rhythm 'framing' and the 19th-century type of rhythm 'alternating', marking it respectively as SWWS and WSWS (S - a strong position with higher prominence of stresses, a "strong foot"; W - a strong position with lower prominence of stresses, a "week foot"). ${ }^{10}$ The iambs in Osipov's and Kotlyarevsky's poems are of the framing type, while Shevchenko's iambs represent the alternating type.

The Russian and Ukrainian languages are closely related and have a very similar prosodic structure; if we add close cultural relations, then the similarity of rhythmic factors should not be surprising. The situation is completely different in the case of the Russian and Lithuanian languages. Unlike in Russian, in Lithuanian heavy and light syllables are distinguished and the stress is tonic. Since the location of stress is not fixed in a word, there should not be any problems creating syllabic-accentual verses.

9 Compare Boris Tomashevsky's standpoint that the first two syllables in trochee can be considered its anacrusis, that is, the first strong position in a trochaic verse is on the third syllable: "We have reason to believe that in trochee and dactyl the entire first foot is anacrusis, that is, in trochee we are dealing with a disyllabic, in dactyl a trisyllabic anacrusis"(Tomashevsky 1925: 111, footnote 1). Tomashevsky, however, confuses metrical structures with the rhythmic ones.

10 The prominence of a strong position is not an absolute parameter, but relative, being determined by its context: the high incidence of stresses can characterise also non-prominent positions, but it has to be lower there than in the neighbouring strong positions. 


\section{Jurgis Baltrušaitis: comparative analysis of the rhythm of Russian and Lithuanian binary tetrameters}

Jurgis Baltrušaitis (1873-1944), a Symbolist poet, wrote little and published even less, but his œuvre was nevertheless a significant phenomenon, first in Russian, then in Lithuanian culture. ${ }^{11}$ Unlike his contemporaries Valery Bryusov and Konstantin Balmont, Baltrušaitis did not experiment with verse forms. Iambic and trochaic tetrameters constitute a significant part of his heritage and provide sufficient material for statistical analysis.

The rhythmic structure of Baltrušaitis' Lithuanian T4 and I4 is studied on the basis of Juozas Girdzijauskas's data (Girdzijauskas 1975: 45-59 and 1979: 169-180). ${ }^{12}$ The material for the statistical analysis of Baltrušaitis' Russian poems was assembled from the collection compiled by Juozas Tumelis (Baltrušaitis 1983), which contained the more important poems from three previously published poetry collections and also a few previously unpublished texts.

The specificity of the approach offered below is that the data of T4 and I4 are studied together (not separately, as it is traditionally done).

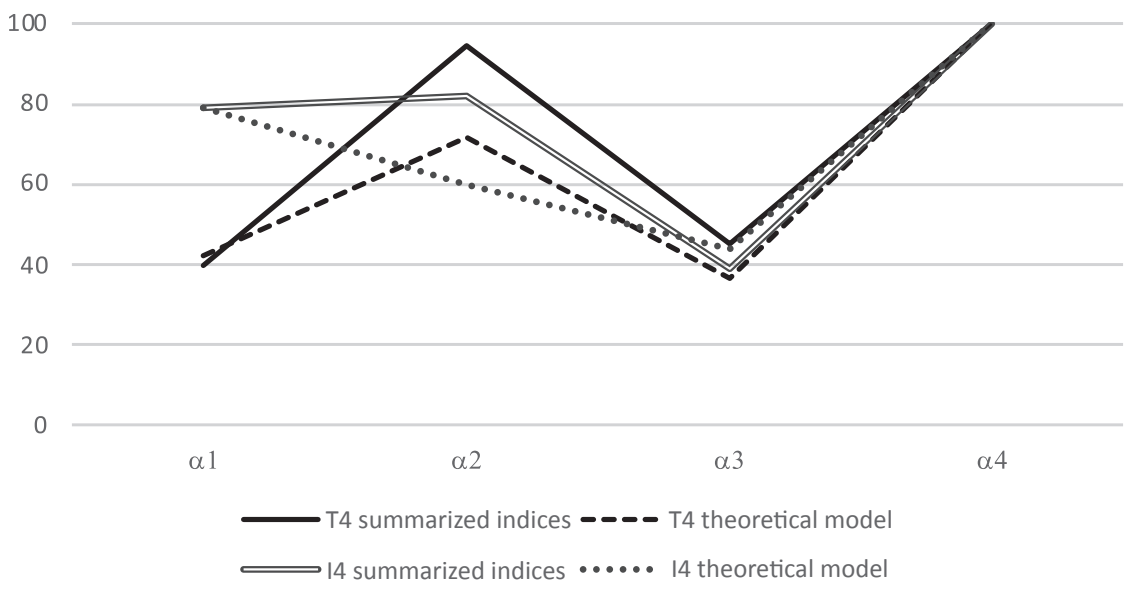

Chart 4. Lithuanian binary tetrameters: summarized indices and the theoretical model

11 Andrey Bely in his analysis of Baltrušaitis's unpublished poems ("Ex Deo nascimur") called him "a truly beautiful poet" (Bely 1974: 426).

12 Girdzijauskas presents only the data on the distribution of rhythmic forms, but it allows for an easy reconstruction of the parameters of stressedness in the strong positions of the verse. 
First, let us consider the summarized indices of T4 and I4 in comparison with the theoretical models of these verse metres, which have also been calculated based on Girdzijauskas's data relying on the rhythmic dictionary of the language.

The rhythmic contours of Lithuanian T4 and I4 differ significantly. In the case of the trochee, both its theoretical model and indices of the actual verse represent a clearly expressed alternating type (WSWS), with the differences between the $\mathrm{S}$ and $\mathrm{W}$ positions in the verse being more prominent than in the theoretical model. The second difference concerns the average stressedness of the strong positions of the verse: in the theoretical model, this index is $62.4 \%$, in the verse it is $69.9 \%$.

As for iamb, the contours of the theoretical model and verse rhythm do not coincide. The theoretical model is characterized by a framing rhythm (SWWS), which is also particular to the theoretical model of Russian I4, whereas the indices of the stressedness of the strong positions in verse virtually coincide in the first half of the verse $\left(\alpha_{1} \approx \alpha_{2}\right)$; in Russian verse, this rhythm is particular to the poetry from the beginning of the 19th century; Kiril Taranovsky called such rhythmic type the transitional rhythm (that is, the transition from the 18th century framing rhythm to the Pushkinian tradition of alternating iamb, compare Taranovsky 2010: 91). As for the average stressedness of the strong position, here too the index of the theoretical model $(70.7 \%)$ is considerably lower than the index of verse (74.9\%). That is, in verse, the strong positions in T4 and I4 are more clearly contrasted with the weak ones as compared to the theoretical model. It should be noted that the same patterns function in Russian versification and it is possible that they are universal in the case of syllabic-accentual verse.

Now we turn our attention to the rhythmics of Baltrušaitis's rhythmics and introduce first the data of his Russian poetry.

Table 1. The stressedness of strong positions in Baltrušaitis's iambic and trochaic tetrameters

\begin{tabular}{|c|l|l|l|l|l|c|}
\hline & $\alpha_{1}$ & $\alpha_{2}$ & $a_{3}$ & $\alpha_{4}$ & Average & Number of lines \\
\hline I4 & $93.4 \%$ & $95.0 \%$ & $59.2 \%$ & $100 \%$ & $86.9 \%$ & 479 \\
\hline T4 & $72.7 \%$ & $100 \%$ & $53.2 \%$ & $100 \%$ & $81.5 \%$ & 370 \\
\hline
\end{tabular}

The main differences in the rhythmics of iambic and trochaic tetrameters lie, first, in the fact that the average stressedness of trochee is smaller than in iamb - T4 is "lighter" than I4. Secondly, the dissimilative rhythm has reached 
its maximum in T4: the verse has two accentual constants, on the third and on the seventh syllable.

Compare the sound of T4 and I4 (the number of the rhythm form is indicated after each verse line). T4:

\begin{tabular}{|c|c|}
\hline Дышит полночь тенью жуткой.. & \\
\hline Тьма в окне и в сердце тьма... & \\
\hline Сладость - малая минутка... & \\
\hline Горечь - долгая зима... & \\
\hline Чуткий дух в тоске бессменной & \\
\hline Внемлет ночи у окна... & \\
\hline Велика, неизреченна & \\
\hline Неземная тишина... & \\
\hline Но с годами понемногу & \\
\hline Тают тайные круги, & \\
\hline И к последнему порогу & \\
\hline Приближаются шаги... & \\
\hline Слышен звон освобожденья & \\
\hline В бое медленных часов, & \\
\hline И сдвигает бег мгновенья & \\
\hline Неразгаданный засов... & \\
\hline Будет час, и дрогнут петли, & \\
\hline Дверь глухая задрожит, & \\
\hline И узнаю, тьма ли, свет ли & \\
\hline Смертный выход сторожит! & \\
\hline
\end{tabular}

In Baltrušaitis's Russian T4, there are no forms III and V (where the third syllable is unstressed). Next are the data on I4:

$\begin{array}{ll}\text { Как трудно высказать - нелживо, } & \text { IV } \\ \text { Чтоб хоть себя не обмануть - } & \text { IV } \\ \text { Чем наше сердце втайне живо, } & \text { I } \\ \text { О чем, тоскуя, плачет грудь... } & \text { I } \\ \text { Речь о мечтах и нуждах часа } & \text { II } \\ \text { В устах людей - всегда - прикраса, } & \text { I } \\ \text { И силен у души - любой - } & \text { III }\end{array}$




$\begin{array}{ll}\text { Страх наготы перед собой, - } & \text { VI } \\ \text { Страх истины нелицемерной } & \text { V } \\ \text { Иль, брат боязни, хитрый стыд, } & \text { I } \\ \text { О жалком плачущих навзрыд, } & \text { IV } \\ \text { Чтоб точным словом, мерой верной } & \text { I } \\ \text { Того случайно не раскрыть, } & \text { IV } \\ \text { Чему сокрытым лучше быть... } & \text { I }\end{array}$

Now compare the rhythmic indices of Baltrušaitis's Lithuanian and Russian T4 and I4:

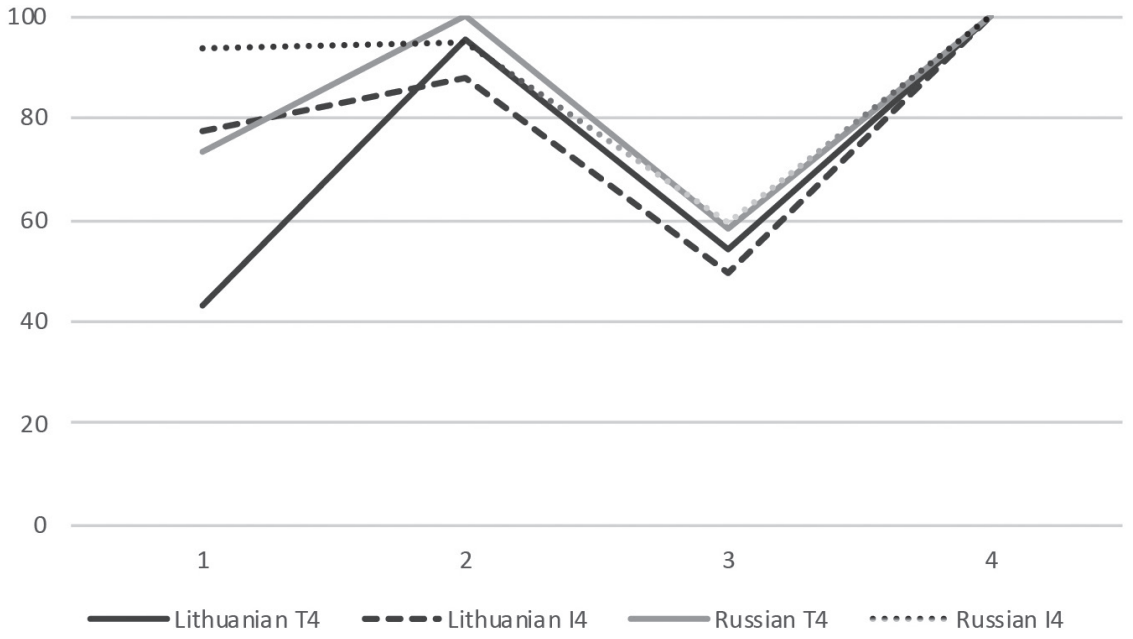

\section{Chart 5. Baltrušaitis's Lithuanian binary tetrameters compared to his Russian ones}

The presented data are quite telling. The rhythmic contour of the verse is more dependent on verse meter than on language. The alternating rhythmic type is predominant, but it is much more clearly expressed in the trochee than in the iamb, and Baltrušaitis's Russian I4 is generally close to the transitional rhythm of the beginning of the 19th century. In other words, Taranovsky's laws also apply to Lithuanian verse and operate not only in Baltrušaitis's poetry, but more or less in every author studied by Girdzijauskas (T4 has been described in seven and I4 in nine 20th-century poets). In all these cases T4 is characterized by a clearly expressed alternating rhythm (see below).

As for the linguistic differences, the index of stressedness in both T4 and I4 in the first three strong positions of Baltrušaitis's Russian verse is stronger than in Lithuanian verse: the average stressedness in strong positions in Lithuanian 
$\mathrm{T} 4$ is $73.1 \%$ (the lowest corresponding index in Lithuanian poetry is Binkis's $62.7 \%$ ), whereas the average stressedness in strong positions in Russian T4 is $82.9 \%$; in I4 the data is $78.8 \%$ and $86.9 \%$, respectively. To use Mikhail Gasparov's terminology, Baltrušaitis's Russian binary verses are heavier than in his Lithuanian poems.

The T4 rhythmic indexes of Maironis's (Jonas Mačiulis), Faustas Kirša's, Juozas Tysliava's and Kazys Binkis's poetry, were calculated for this paper:

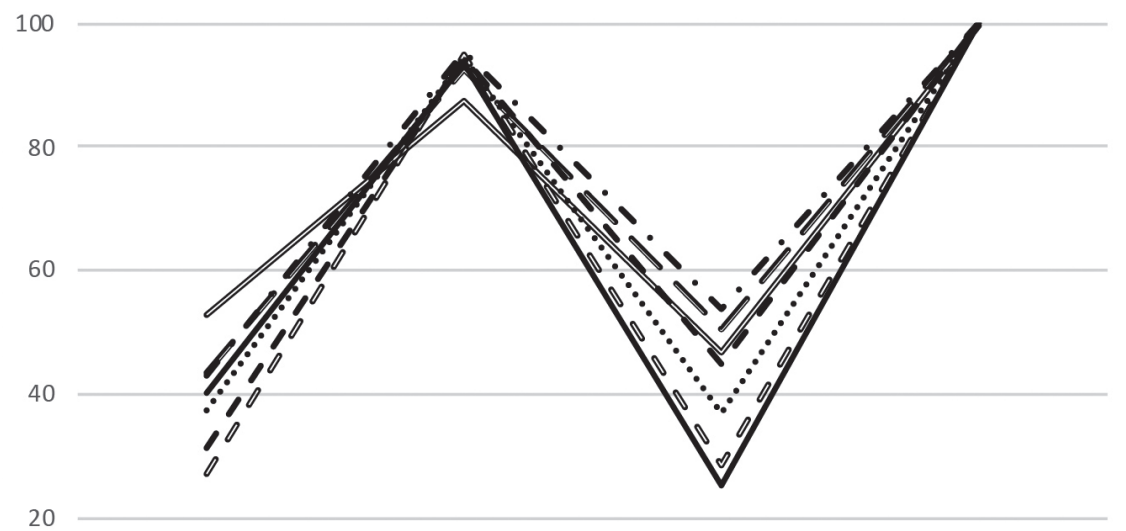

0

$$
\begin{aligned}
& \alpha 1 \\
& \alpha 2 \\
& \alpha 3 \\
& \alpha 4 \\
& \begin{array}{l}
\text { Maironis }- \text { Sruoga } \quad-\text { - Baltrušaitis } \rightleftharpoons \text { Kirša } \\
\text {...... Tysliava } \quad \text { - Binkis Mieželaitis }
\end{array}
\end{aligned}
$$

\section{Chart 6. The rhythmic indexes of Lithuanian T4}

This reveals that Baltrušaitis's Lithuanian T4 fits organically into the context of his contemporary poetry.

However, the rhythmics of Lithuanian I4 is characterized by a greater diversity. 


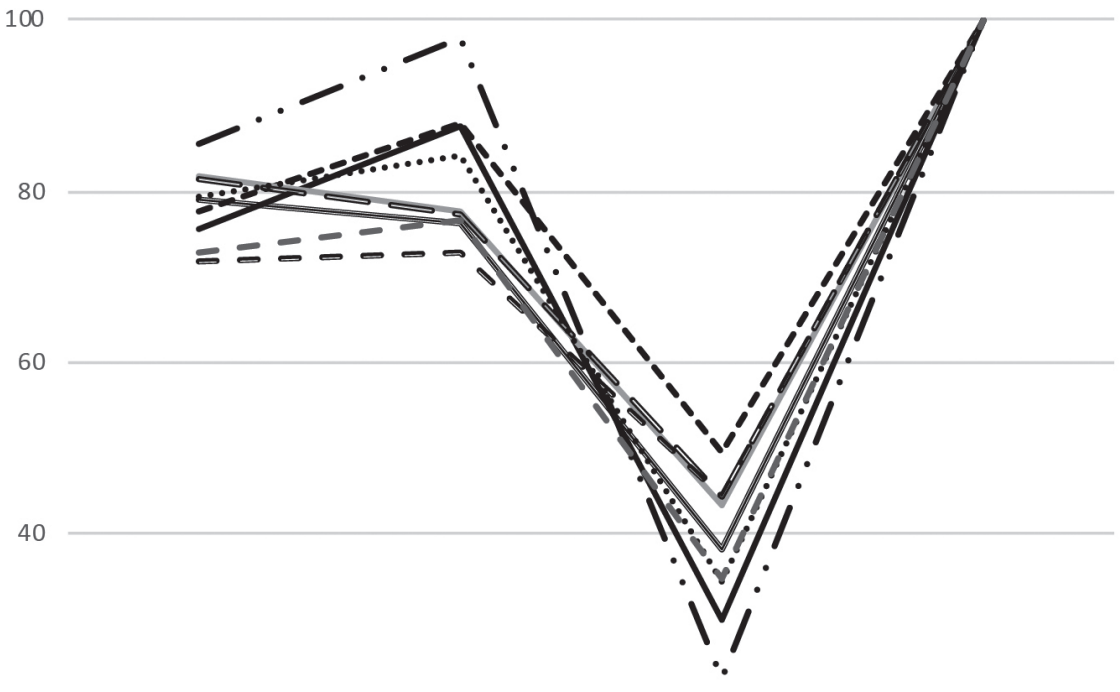

0

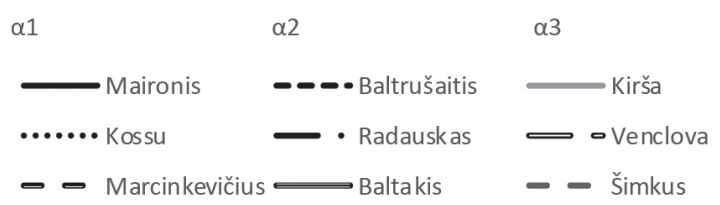

\section{Chart 7. The rhythmic indices of Lithuanian 14}

One can outline three different types of rhythm: alternating rhythm similar with Pushkin's I4 (for example, Maironis and Henrikas Radauskas); framing rhythm (Faustas Kirša and Algimantas Baltakis), which corresponds the most to the theoretical model, and intermediary rhythm (Marcinkevičius and Jonas Šimkus). In each case, the divergence from T4 is determined by the law of stabilisation functioning in the first strong position of the iambic line.

Why are the rhythmic patterns of Lithuanian binary tetrameters close to the Russian ones, despite the obvious differences in the prosody of the natural languages? It would be difficult to explain away as possible cultural influence. It seems that we might find the reason in the counteraction of two factors: language and rhythmics. From the perspective of language, not the existence, or lack thereof, of the phonological length of vowels nor the tonic basis of Lithuanian stress are of decisive importance, but, as in Russian, its mobile 
nature. The rhythmic factor is the existence of the stress constant on the last strong position in the verse line, ${ }^{13}$ and therefore the existence of this constant does not derive from the prosodic properties of the language.

The analysis of T4 and I4 in different poetic traditions demonstrates that the stress profiles of these verse metres are almost always considerably different. The only known exception is Estonian verse. In the Estonian language, like in Czech, Hungarian or Finnish, stress is fixed on the first syllable of the word. But only in Estonian iamb does ban on general trans-accentuation in syllabic-accentual verse expand to the beginning of the line, and as a result, in the vast majority of the cases, the iamb is essentially a trochee that has a monosyllabic word added in anacrusis. Therefore, the stress profiles of the strong positions of the iamb and trochee essentially overlap. This is not the case in many other poetic traditions. Compare, for example, the last stanza of Sándor Petőfi's "Reflections" (“Tünődés", 1841), where each verse begins with an inverted foot:

Akár a lyányka hü ajkáról

Szedvén új édes csókokat,

Akár ha szárnya képzetemnek

Dicsőbb világokhoz ragad.

The poem is, as a whole, syllabic-accentual ${ }^{14}$, but the above-cited verses compensate for the violation of the tonic principle quantitatively: \#نं-\#. However, this compensation is not mandatory in Hungarian (compare lines 7-8 of the

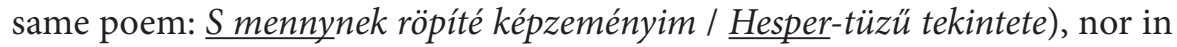
Finnish and Czech iamb. Compare the beginning of Karel Hynek Mácha’s famous poem "May" (“Máj”, 1836; see Jakobson 1979):

Byl pozdní večer - první máj -

Večerní máj - byl lásky čas.

Hrdliččin zval ku lásce hlas,

Kde borový zaváněl háj.

O lásce šeptal tichý mech;

Květoucí strom lhal lásky žel,

13 Of all the authors analysed by Girdzijauskas, only in Kirša's T4 the stressedness of the last strong position is $99.8 \%$ (in all the others there is a stress constant in both in $\mathrm{T} 4$ and I4, that is, it carries a stress in $100 \%$ of the cases).

14 The question of versification system in the Hungarian iamb is quite complicated: it is characterized by both accentual and quantitative restraints (compare Kerek 1971: 18-22). 
Svou lásku slavík růži pěl,

Růžinu jevil vonný vzdech.

Jezero hladké v křovích stinných

Zvučelo temně tajný bol,

Břeh je objímal kol a kol;

A slunce jasná světů jiných

Bloudila blankytnými pásky,

Planoucí tam co slzy lásky.

Compare also the first two quatrains of Kaarlo Kramsu poem "Uusi aika" (“The New Era”, 1887):

Käy myrsky, murtain kaikki voimallansa,

Syvästi aika uusi hengähtää;

Ja luulot vanhat horjuu juurillansa,

Pyhyydet muinaisuuden häviää.

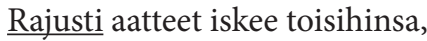

Ja eestä niiden urhot uhrataan.

Ei luota orja enää kahleihinsa:

Vapaana riehuin tuntee voimiaan.

The second, fourth, fifth and eighth lines of the poem begin with a threesyllable word. The beginning of the second and fifth lines are made up of three light syllables: $\cup \cup \cup$, at the beginning of the fourth and eighth lines the second syllables are heavy: $\dot{\cup} \cup$.

Due to the admissibility of these types of inversions the rhythmic structure of iambic verse is significantly different from the trochaic one, especially in the first distich.

\section{Concluding remarks: the typology of rhythm}

An analysis of Baltrušaitis's rhythmics of binary tetrameters demonstrates that the same rhythmic patterns occur in his Russian and Lithuanian poetry. A comparison with analogous data on other Lithuanian poets confirms this hypothesis. But how universal are the aforementioned patterns?

The Ukrainian and Russian languages are closely related, and their prosodic systems are similar. If we take into consideration their close cultural contacts, 
it may seem that similar tendencies in the rhythmics of these verses should be found in the area of their origin and influences. Cultural contacts may be a more important factor than the kinship or similarity of the languages. The structures of German and Russian languages are significantly different both in the field of prosody and syntax, which did not hinder Lomonosov from implanting into Russian poetic culture not only in the verse meters brought from Germany, but also the rhythm characteristic to German iamb. The prosodic systems of Lithuanian and Russian languages are quite dissimilar. Differently from Russian, Lithuanian has the contrast of heavy and light syllables and pitch-accent. It is also difficult to explain Lithuanian rhythmics with cultural influences. Therefore, the reasons of similarities must be found elsewhere.

It can be assumed that there are two reasons, the first of which is linguistic, the other follows from versification. The linguistic cause lies in the free stress (it is not important, whether the stress is dynamic or tonic) and the abundance of polysyllabic words. The rhythmic factor lies in the so-called rhythmic constant, which results in the mandatory stress on the last strong position. It has to be emphasized that this constant is not in any way linguistically motivated, it is purely a phenomenon of versification. As a consequence, usually the penultimate strong position is contrastively weaker: ...WS (Taranovsky calls it regressive dissimilation). Thus, there remain only two possibilities: either the dissimilative rhythm WSWS or the framing rhythm SWWS. The rhythmics of Russian I4 in the 18th century follows the framing impulses of the languages, while in the beginning of the 19th century marks the transition to the dissimilative rhythm.

It is worthwhile to compare the previous observations with the situation of binary meters in the languages where the stress is fixed on the first syllable. In the case of T4, the conflict between the language and verse meter usually does not occur and in general, a dissimilative rhythm evolves, however, not regressive, but progressive: SWSW, while the first $\mathrm{S}$ forms the accentual constant. In the Hungarian, Czech and Finnish I4 the tendency of inverting the first verse foot occurs, and as a result, there are no accentual constants in the verse.

At present, we have the rhythmical data of a number of poetic traditions (Russian, Ukrainian, Polish, Czech, Serbian, Bulgarian, Lithuanian, English, German, Dutch, Finnish, Estonian, among others) that have been acquired with a comparable method. The data reveals that of the 16 possible combinations of higher stressedness (S) and lower stressedness (W) in verse, only four have found widespread use: SSSS (for example, German I4, Lomonosov's early iambs), SWSW (progressive dissimilation: Czech T4), SWWS (framing 
rhythm: 18th-century Russian I4) and WSWS (regressive dissimilation: Russian and Lithuanian T4, 19th-century Russian I4).

It has to be noted, that all these results are obtained only with the statistics of main stresses; adding the secondary stresses (in the languages where it exists) to the calculation changes the results. The same can be said about phrasal stresses, for instance, in Estonian verse. Here a clear chronological and aesthetic difference between the "traditionalist" and "modernist" poets can be observed: in the verse of the former, the accentual peak of the verse line is on the penultimate strong position, in the verse of the latter - on the last one. It is remarkable that this regularity characterizes both $\mathrm{T} 4$ and I4.

The rhythm of a particular poem is formed as a combined effect of different factors. These factors are verse meter, prosody of language in its broadest meaning (including the syntactic prosody) and the regularities of rhythm itself. But verse rhythm can also depend on the era, style and other aesthetic factors. And finally, rhythm can occur as the consequence of conscious modelling of an author. ${ }^{15}$

\section{References}

Annensky, Innokenty 1990. Stikhotvorenija i tragedii. Leningrad: Sovetskij pisatel'.

Baevsky, Vadim 2001. Lingvisticheskie, matematicheskie, semioticheskie i komp’juternye modeli v istorii i teorii literatury. Moskva: Jazyki slavjanskoj kultury.

Baltrušaitis, Jurgis 1983. Derevo v ogne. Stikhi. Vilnius: Vaga.

Bely, Andrei 1910. Simvolizm. Kniga statej. Moskva: Musaget.

Bely, Andrei 1974. A Belo rankraštis apie J. Baltrušaičio lyriką. Parengè V. Kubilius ir D. Straukaitè. In: Lietuvių poetikos tyrinējimai (Literatūra ir kalba XIII). Vilnius: Vaga, 424-452.

Fedotov, Oleg 2015. Mezhdu Motsartom i Saleri. O poeticheskom dare Nabokova. Moskva: Flinta.

Fedotov, Oleg 2017. Otzvuki formalizma v metapoetike Vladimira Nabokova. In: Pilshchikov, Igor; Levchenko, Jan (eds.), Epokha "ostranenija": Russkij formalizm $i$ sovremennoe gumanitarnoe znanie. Moskva: Novoe literaturnoe obozrenie, 487-496.

15 This research was supported by Estonian Research Council grant no. PUT1231. I am highly obliged to Igor Pilshchikov for his comments and improvements. 
Girdzijauskas, Juozas 1975. Lietuviu eiledara (XX amžius). Filologios mokaly daktaro laipsniondisertacija. Priedai. Vilnius. (Typescript).

Girdzijauskas, Juozas 1979. Lietuvių eilèdara XX amžius. Vilnius: Mokslas.

Hansen-Löve, Aage 2000. Estetika «kaliptiki»: apollinskie kontseptsii v metafizicheskoj poetike Nabokova. In: Revue des études slaves 72(3-4), 311-317. https://doi.org/10.3406/slave.2000.6663

Hollander, John 1959. The Metrical Emblem. In: The Kenyon Review 21(2), 279-296.

Hollander, John 1975. Vision and Resonance: Two Senses of Poetic Form. Oxford: Oxford University Press.

Jakobson, Roman 1979. Toward a Description of Mácha’s Verse. Translated by Peter and Wendy Steiner. In: Jakobson, Roman. Selected Writings. Vol. V: On Verse, Its Masters and Explorers. The Hague, Paris, New York, 433-485.

Karlinsky, Simon (ed.) 2001. Dear Bunny, Dear Volodya. The Nabokov-Wilson Letters, 1940-1971. Revised and Expanded Edition. Berkeley, Los Angeles, London: University of California Press.

Kazartsev, Evgenij 2017. Sravnitel'noe stikhovedenie: metrika i ritmika. Sankt-Peterburg: Izdatel'stvo RGPU im. A. I. Gertsena.

Kerek, Andrew 1971. Hungarian Metrics: Some Linguistic Aspects of Iambic Verse. Bloomington: Indiana University Press.

Khodasevich, Vladislav 2012. Andrei Bely. In: Khodasevich, Vladislav, Nekropol'. Vospominanija. Moskva: Statut, 41-63.

Lotman, Mihhail; Lotman, Maria-Kristiina 2018. Eesti silbilis-rõhulise rütmika jooni: neliktrohheus ja -jamb 19. sajandi teisel poolel ja 20. sajandi alguses. Tallinn: EKSA.

Mazur, Sergei 1990. Erotika stikha. Germenevticheskij etjud. In: Daugava 10/160, 88-94.

Nabokov, Vladimir 1964. Notes on prosody. In: Eugene Onegin: A novel in verse, by Aleksandr Pushkin, translated from the Russian, with a commentary, by Vladimir Nabokov. Vol. 3. London: Routledge and Kegan Paul, 448-540.

Nabokov, Vladimir 1991. The Gift. Translated by M. Scammell with the collaboration of the author. New York: Vintage International.

Pilshchikov, Igor 2017. Ponjatija «stikh», «metr» i «ritm» v russkoj stikhovedcheskoj traditsii. In: Moldovan, Aleksandr (ed.), Trudy instituta russkogo jazyka im. V. V. Vinogradova. XI: Slavjanskij stikh. Moskva: Institut russkogo jazyka im. V. V. Vinogradova RAN, 12-25. 
Pilshchikov, Igor 2019. Rhythmical Ambiguity: Verbal Forms and Verse Forms. In: Studia Metrica et Poetica 6(2), 53-73. https://doi.org/10.12697/smp.2019.6.2.02

Põldmäe, Jaak 1975. Eesti silbilis-rõhulise värsisüsteemi uurimise meetod ja Betti Alveri poeemide nelikjambi rütm. In: Huno Rätsep (ed.), Keele modelleerimise probleeme 5 (Tartu Riikliku Ülikooli Toimetised 363), Tartu: TRÜ, 163-233.

Taranovsky, Kiril 1953. Ruski dvodelni ritmovi I-II. Beograd: Naučna knjiga.

Taranovsky, Kiril 2000. Chetyrekhstopnyj jamb Andreja Belogo. In: Taranovsky, Kiril, O poezii i poetike. Moskva: Jazyki russkoj kul'tury, 300-318.

Taranovsky, Kiril 2010. Russkie dvuhslozhnye razmery. Stat'i o stikhe. Moskva: Jazyki slavjanskoj kul'tury.

Tomashevsky, Boris 1923. Russkoe stikhoslozhenie. Petrograd: Academia.

Tomashevsky, Boris 1925. Teorija literatury (Poetika). Petrograd: Gosudarstvennoe izdatel'stvo.

Tomashevsky, Boris 1929. Pjatistopnyj jamb Pushkina. In: Tomashevsky, Boris, O stikhe. Leningrad: Priboj, 138-253.

Trubetzkoy, Nikolai 1987. Izbrannye trudy po filologii. Moskva: Progress.

Shengeli, Georgy 1923. Traktat o russkom stikhe. Chast' I. Organicheskaja metrika. Moskva, Petrograd: Gosudarstvennoe izdatel'stvo.

Vasyutochkin, Georgy 1968. O raspredelenii form chetyrekhstopnogo jamba v stikhotvornykh tekstakh. In: Kholshevnikov, Vladislav (ed.), Teorija stikha. Leningrad: Nauka, 125-155. 